\title{
SALICYLIC ACID AS AN ATTENUATOR OF SALT STRESS IN SOURSOP ${ }^{1}$
}

\author{
ANDRÉ ALISSON RODRIGUES DA SILVA ${ }^{2 *}$, GEOVANI SOARES DE LIMA ${ }^{3}$, CARLOS ALBERTO VIEIRA DE \\ AZEVEDO $^{2}$, LUANA LUCAS DE SÁ ALMEIDA VELOSO ${ }^{2}$, HANS RAJ GHEYI ${ }^{4}$
}

\begin{abstract}
The search for alternatives that enable the use of saline waters in agriculture has become constant. In this context, the objective was to evaluate the effects of salicylic acid in mitigating salt stress effects on the growth and gas exchange of soursop cv. 'Morada Nova'. The study was conducted in a greenhouse, in the municipality of Campina Grande - PB, Brazil. Treatments were distributed in randomized blocks, in a $5 \times 4$ factorial arrangement, corresponding to five levels of electrical conductivity of irrigation water - ECW $\left(0.8 ; 1.6 ; 2.4 ; 3.2\right.$ and $\left.4.0 \mathrm{dS} \mathrm{m}^{-1}\right)$ and four concentrations of salicylic acid - SA $(0 ; 1.2 ; 2.4$ and $3.6 \mathrm{mM})$, with three replicates. Irrigation with saline water compromised the growth and gas exchange of soursop cv. 'Morada Nova'. However, exogenous application of salicylic acid induced tolerance to salt stress in soursop plants, as their growth, transpiration, stomatal conductance, photosynthesis and instantaneous carboxylation efficiency were favored by the application of salicylic acid, even when exposed to water salinity.
\end{abstract}

Keywords: Annona muricata L.. Saline water. Salinity mitigation.

\section{ÁCIDO SALICÍLICO COMO ATENUADOR DO ESTRESSE SALINO DE GRAVIOLEIRA}

RESUMO - A busca por alternativas que possibilitem o uso de águas salinas na agricultura tem se tornado constante. Neste contexto, objetivou-se, avaliar os efeitos do ácido salicílico na mitigação do estresse salino no crescimento e nas trocas gasosas da gravioleira cv. Morada Nova. O estudo foi conduzido em casa de vegetação, no município de Campina Grande - PB. Os tratamentos foram distribuídos em blocos casualizados, em arranjo fatorial $5 \times 4$, sendo cinco níveis de condutividade elétrica da água de irrigação - CEa $(0,8 ; 1,6 ; 2,4$; 3,2 e 4,0 dS m$\left.{ }^{-1}\right)$ e quatro concentrações de ácido salicílico - AS $(0 ; 1,2 ; 2,4$ e 3,6 mM), com três repetições. A irrigação com águas salinas comprometeu o crescimento e as trocas gasosas da gravioleira cv. Morada Nova. Entretanto, a aplicação exógena do ácido salicílico induziu a tolerância ao estresse salino a gravioleira, visto que, as plantas tiveram seu crescimento, transpiração, condutância estomática, fotossíntese e eficiência instantânea da carboxilação beneficiadas pela aplicação do ácido salicílico, mesmo quando expostas a salinidade da água.

Palavras-chave: Annona muricata L.. Águas salinas. Mitigação da salinidade.

\footnotetext{
${ }^{*}$ Corresponding author

${ }^{1}$ Received for publication in 03/20/2020; accepted in 09/11/2020.

Paper extracted from the doctoral thesis of the first author.

${ }^{2}$ Academic Unit of Agricultural Engineering, Universidade Federal de Campina Grande, Campina Grande, PB, Brazil; andrealisson_cgpb@hotmail.com - ORCID: 0000-0001-9453-1192, cvieiradeazevedo@gmail.com - ORCID: 0000-0001-7336-1243, luana_lucas_15@hotmail.com - ORCID: 0000-0003-0537-7985.

${ }^{3}$ Academic Unit of Agricultural Sciences, Universidade Federal de Campina Grande, Pombal, PB, Brazil; geovani.soares@pq.cnpq.br ORCID: 0000-0001-9960-1858.

${ }^{4}$ Nucleus of Soil and Water Engineering, Universidade Federal do Recôncavo da Bahia, Cruz das Almas, BA, Brazil; hans@pq.cnpq.br ORCID: 0000-0002-1066-0315.
} 


\section{INTRODUCTION}

Soursop (Annona muricata L.) is a fruit tree belonging to the Annonaceae family, native of the tropical areas of Central America, introduced to Brazil by the Spanish and Portuguese in the $16^{\text {th }}$ century (SÁNCHEZ et al., 2018). Its commercial cultivation is recent; however, its production has increased in recent years due to the advances in the agroindustry and, above all, its use by the pharmaceutical industry (SÃO JOSÉ et al., 2014; BENTO et al., 2016).

Source of vitamin C, calcium, carbohydrates and antioxidant substances such as acetogenins, alkaloids and flavonoids, soursop helps protect the human body against oxidative stress, acting in the prevention of a series of chronic degenerative disorders (DAUDA et al., 2018). Due to population growth, combined with the increase in demand for food and the reduction in water availability both quantitatively and qualitatively, it is necessary to use marginal quality water, that is, waters with high concentrations of salts (RODRIGUES et al., 2020). However, salinity is one of the most challenging and potential threats to agriculture, especially in semiarid regions (KHAN et al., 2019).

Excess salts in water inhibit plant growth due to some factors such as toxicity of ions $\left(\mathrm{Na}^{+}\right.$and $\left.\mathrm{Cl}^{-}\right)$, osmotic and oxidative stress, degradation of pigments, alteration of metabolic pathways, and inhibition of photosynthesis and nutrient absorption (BISTGANI et al., 2019; MAGALHÃES et al., 2020). Silva et al. (2018), studying the growth and gas exchange of soursop seedlings under irrigation with saline water, found that water salinity from 0.5 $\mathrm{dS} \mathrm{m}^{-1}$ negatively affected their gas exchange and growth. Reductions in soursop growth due to the increase in the salinity level of irrigation water were also identified by Veloso et al. (2019).

Thus, it is necessary to seek strategies that enable the cultivation of soursop, and these alternatives particularly include the use of elicitors, such as salicylic acid, which acts in improving the efficiency of metabolic processes, resulting in acclimation to abiotic stresses, including salt and water stresses (SILVA et al., 2019; ANDRADE et al., 2020).

Salicylic acid is a plant hormone that plays several physiological roles in plants, including growth, flower induction, nutrient absorption, ethylene biosynthesis, stomatal closure, and photosynthesis. In addition, it increases the activity of antioxidant enzymes such as peroxidases, superoxide dismutase and catalase (SZEPESI, 2008). Some studies have reported that the exogenous application of salicylic acid may increase tolerance to salt stress in sunflower (NOREEN et al., 2017), barley (PIRASTEH-ANOSHEH et al., 2017) and tomato (GHARBI et al., 2018). However, there is no information on its use in the cultivation of soursop grown under irrigation with saline water.

It should also be considered that the effect of salicylic acid depends on several factors, including concentration, plant species and stage of development and mode of application (POÓR et al., 2019). In view of the above, the objective of this study was to evaluate the effect of concentration of salicylic acid in mitigating salt stress effects on the growth and gas exchange of soursop cv. 'Morada Nova'.

\section{MATERIAL AND METHODS}

The experiment was carried out in a protected environment (greenhouse) belonging to the Academic Unit of Agricultural Engineering - UAEA of the Federal University of Campina Grande UFCG, located in Campina Grande, Paraíba, Brazil, at the geographical coordinates $7^{\circ} 15^{\prime} 18^{\prime \prime}$ South latitude, 35'52'28' West longitude and average altitude of $550 \mathrm{~m}$. Air temperature (maximum and minimum) and relative humidity of air data are shown in Figure 1.

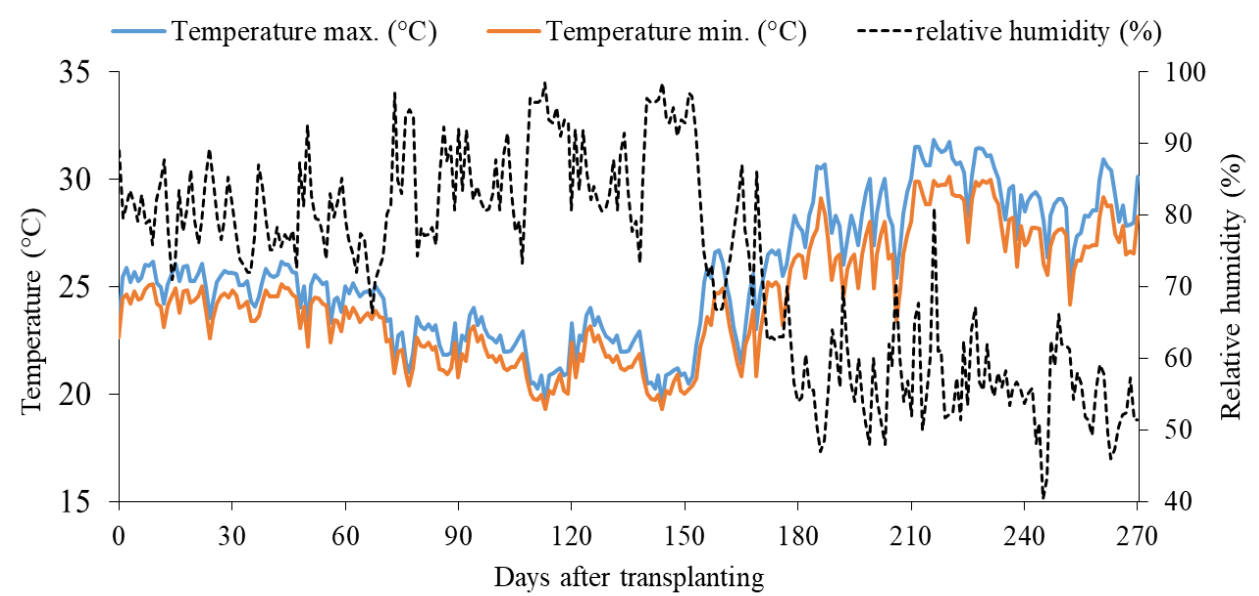

Figure 1. Air temperature (maximum and minimum) and relative humidity of air inside the greenhouse along the experimental period. 
The treatments consisted of five levels of electrical conductivity of irrigation water - $\mathrm{ECw}(0.8$; $1.6 ; 2.4 ; 3.2$ and $\left.4.0 \mathrm{dS} \mathrm{m}^{-1}\right)$ and four concentrations of salicylic acid - SA $(0 ; 1.2 ; 2.4$ and $3.6 \mathrm{mM})$, in a 5 $\mathrm{x} 4$ factorial arrangement, distributed in randomized blocks, with three replicates, totaling 60 experimental units. Salicylic acid (SA) concentrations were established according to a study conducted by Abbaszadeh et al. (2020).

The cultivar 'Morada Nova' was chosen because it is the most appreciated by producers, composing most commercial plantations in Brazil, besides having larger fruits, which can weigh up to $15 \mathrm{~kg}$, and higher production compared to other cultivars (VELOSO et al., 2018). The seedlings were produced sexually over a period of 330 days before transplanting. After this period, they were transplanted to plastic recipients.

During the acclimation period in the greenhouse (30 days), the plants were irrigated with low-salinity water $\left(0.38 \mathrm{dS} \mathrm{m}^{-1}\right)$ and then the treatments were applied.

The experiment was conducted using plastic pots adapted as drainage lysimeters, with capacity of $120-\mathrm{L}$, filled with a $1.0-\mathrm{kg}$ layer of crushed stone followed by $160 \mathrm{~kg}$ of soil classified as Neossolo Regolitico (Psamments - UNITED STATES, 2014), collected at $0-30 \mathrm{~cm}$ depth in the municipality of Lagoa Seca-PB, whose physico-chemical characteristics (Table 1) were determined according to Teixeira et al. (2017).

Table 1. Chemical and physical attributes of the soil used in the experiment, before the application of the treatments.

\begin{tabular}{|c|c|c|c|c|c|c|c|c|c|}
\hline \multicolumn{10}{|c|}{ Chemical characteristics } \\
\hline \multirow{2}{*}{$\begin{array}{c}\mathrm{pH}\left(\mathrm{H}_{2} \mathrm{O}\right) \\
(1: 2.5) \\
\end{array}$} & \multirow{2}{*}{$\begin{array}{c}\mathrm{OM} \\
\text { dag kg }^{-1}\end{array}$} & \multirow{2}{*}{$\begin{array}{c}\mathrm{P} \\
\left(\mathrm{mg} \mathrm{kg}^{-1}\right)\end{array}$} & $\mathrm{K}^{+}$ & $\mathrm{Na}^{+}$ & $\mathrm{Ca}^{2+}$ & $\mathrm{Mg}^{2+}$ & $\mathrm{Al}^{3+}+\mathrm{H}^{+}$ & \multirow{2}{*}{$\begin{array}{l}\text { PST } \\
(\%)\end{array}$} & \multirow{2}{*}{$\begin{array}{c}\text { ECse } \\
\left(\mathrm{dS} \mathrm{m}^{-1}\right)\end{array}$} \\
\hline & & & \multicolumn{5}{|c|}{ 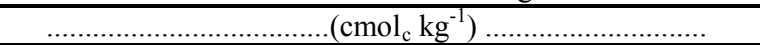 } & & \\
\hline 5.90 & 1.36 & 6.80 & 0.22 & 0.16 & 2.60 & 3.66 & 1.93 & 1.87 & 1.0 \\
\hline \multicolumn{10}{|c|}{ Physical characteristics } \\
\hline \multicolumn{3}{|c|}{ Size fraction $\left(\mathrm{g} \mathrm{kg}^{-1}\right)$} & \multirow{2}{*}{$\begin{array}{l}\text { Textural } \\
\text { class }\end{array}$} & \multicolumn{2}{|c|}{ Water content $(\mathrm{kPa})$} & \multirow[t]{2}{*}{ AW } & \multirow{2}{*}{$\begin{array}{c}\text { Total } \\
\text { porosity } \\
\% \\
\end{array}$} & $\mathrm{BD}$ & PD \\
\hline Sand & Silt & Clay & & $33.42^{*}$ & $\begin{array}{l}1519.5^{* *} \\
\text { dag kg }^{-1}\end{array}$ & & & \multicolumn{2}{|c|}{$\left(\mathrm{kg} \mathrm{dm}^{-3}\right)$} \\
\hline 732.9 & 142.1 & 125.0 & SL & 11.98 & 4.32 & 7.66 & 47.74 & 1.39 & 2.66 \\
\hline
\end{tabular}

$\mathrm{OM}$ - Organic Matter: Walkley-Black Wet Digestion; $\mathrm{Ca}^{2+}$ and $\mathrm{Mg}^{2+}$ extracted with $1 \mathrm{M} \mathrm{KCl}$ at $\mathrm{pH} 7.0 ; \mathrm{Na}^{+}$and $\mathrm{K}^{+}$extracted with $1 \mathrm{M} \mathrm{NH}_{4} \mathrm{OAc}$ at $\mathrm{pH} 7.0 ; \mathrm{Al}^{3+}$ and $\mathrm{H}^{+}$extracted with $0.5 \mathrm{M} \mathrm{CaOAc}$ at $\mathrm{pH}$ 7.0; ESP - Exchangeable sodium percentage; ECse - Electrical conductivity of the saturation extract; SL - Sandy loam; AW - Available water; BD - Bulk density; PD - Particle density; ${ }^{*}$ - Field capacity; ${ }^{* *}$ - Permanent wilting point.

Irrigation waters with different levels of electrical conductivity were prepared by dissolving in local supply water $\left(\mathrm{ECW}=0.38 \mathrm{dS} \mathrm{m}^{-1}\right)$ the salts $\mathrm{NaCl}, \mathrm{CaCl}_{2} .2 \mathrm{H}_{2} \mathrm{O}$ and $\mathrm{MgCl}_{2} \cdot 6 \mathrm{H}_{2} \mathrm{O}$, respectively in the equivalent proportion of $7: 2: 1$, which is commonly found in sources of water used for irrigation in small farms in the Northeast region (MEDEIROS, 1992), based on the relationship between $\mathrm{ECw}\left(\mathrm{dS} \mathrm{m}^{-1}\right)$ and the concentration of salts $\left(\mathrm{mmol}_{\mathrm{c}} \mathrm{L}^{-1}=10^{*} \mathrm{ECw}\right)$ recommended by Richards et al. (1954).

At 30 days after transplanting, irrigation began with the saline waters, adopting an irrigation interval of three days, applying water in each lysimeter according to treatment in order to keep the soil moisture close to field capacity and avoid excessive accumulation of salts in the soil. The volume of water to be applied was determined according to the water needs of the plants, estimated by the water balance, using by Equation 1:

$$
V I=\frac{(V a-V d)}{(1-L F)}
$$

Where:

$\mathrm{VI}=$ volume of water to be applied in the irrigation event $(\mathrm{mL})$;

$\mathrm{Va}=$ volume applied in the previous irrigation event $(\mathrm{mL})$;

$\mathrm{Vd}=$ volume drained $(\mathrm{mL})$;

$\mathrm{LF}=$ Leaching fraction of 0.15 , applied every 15 days.

Salicylic acid concentrations were obtained by dissolution in $30 \%$ ethyl alcohol $(95.5 \%)$ in distilled water, as it is a substance with low solubility in water at room temperature. The adjuvant Wil fix at a concentration of $0.5 \mathrm{~mL} \mathrm{~L}^{-1}$ of solution was used to reduce the surface tension of the drops on the leaf surface in the preparation of the solution.

Foliar applications began at 60 days after transplanting (DAT), with sprays on the abaxial and adaxial faces of the leaves, at intervals of 30 days, using a backpack sprayer between 17:00 and 17:45 $\mathrm{h}$. The sprayer used is a Jacto XP model from Jacto ${ }^{\circledR}$ with capacity of $12-\mathrm{L}$, working pressure (maximum) of 88 psi ( 6 bar) and JD 12P nozzle, and the average volume applied per plant was $400 \mathrm{~mL}$.

Nitrogen, phosphorus and potassium 
fertilizations were based on the recommendation of Cavalcante (2008) for soursop. Urea, monoammonium phosphate and potassium chloride were used as sources of nitrogen, phosphorus and potassium.

To meet the requirement of micronutrients, a nutrient solution with $1.0 \mathrm{~g} \mathrm{~L}^{-1}$ containing: $\mathrm{N}(15 \%)$, $\mathrm{P}_{2} \mathrm{O}_{5}(15 \%), \mathrm{K}_{2} \mathrm{O}(15 \%), \mathrm{Ca}(1 \%), \mathrm{Mg}(1.4 \%), \mathrm{S}$ $(2.7 \%), \mathrm{Zn}(0.5 \%), \mathrm{B}(0.05 \%), \mathrm{Fe}(0.5 \%), \mathrm{Mn}$ $(0.05 \%), \mathrm{Cu}(0.5 \%)$ and $\mathrm{Mo}(0.02 \%)$ was applied on the leaves, adaxial and abaxial sides, using a backpack sprayer.

During the experiment, all the tillage and phytosanitary practices recommended for the crop were performed, monitoring the emergence of pests and diseases and adopting control measures when necessary.

Treatment effects were evaluated based on gas exchange: stomatal conductance ( $g s)$, transpiration $(E), \mathrm{CO}_{2}$ assimilation rate $(A)$, internal $\mathrm{CO}_{2}$ concentration $(\mathrm{Ci})$, instantaneous water use efficiency (WUEi) and instantaneous efficiency of carboxylation $(C E i)$; and on growth variables: plant height $(\mathrm{PH})$, stem diameter (SD), relative growth rate in plant height $\left(\mathrm{RGR}_{\mathrm{PH}}\right)$ and relative growth rate in stem diameter $\left(\mathrm{RGR}_{\mathrm{SD}}\right)$.

Gas exchange was determined at 180 DAT, in the third leaf, counted from the apex of the main branch of the plant, using irradiation of $1200 \mu \mathrm{mol}$ photons $\mathrm{m}^{-2} \mathrm{~s}^{-1}$ and airflow of $200 \mathrm{~mL} \mathrm{~min}^{-1}$, using the portable photosynthesis meter "LCPro+" from ADC BioScientific Ltda.

Growth was measured at 210 and 270 DAT. $\mathrm{PH}$ was measured using as reference the distance from the plant collar to the insertion of the apical meristem, while SD (mm) was measured two centimeters above the plant collar. Plant height and stem diameter data were used to calculate the relative growth rate, a variable that verifies the growth speed of the plants when comparing the final height with the initial height. The relative growth rate was determined according to the methodology described by Benincasa (2003), using Equation 2:

$$
R G R=\frac{\left(\ln A_{2}-\ln A_{1}\right)}{\left(T_{2}-T_{1}\right)}
$$

Where:

RGR - relative growth rate;

$\mathrm{A}_{1}$ - variable at time $t_{1}$

$\mathrm{A}_{2}-$ variable at time $\mathrm{t}_{2}$;

$\mathrm{T}_{1}$ - time 1 in days;

$\mathrm{T}_{2}$ - time 2 in days;

The data obtained were evaluated by analysis of variance at 0.05 probability level and, in cases of significance; linear and quadratic regression analysis was performed, using the statistical program SISVAR-ESAL (FERREIRA, 2019). In addition to $\mathrm{R}^{2}$, the choice of model was made based on the biological significance of the phenomenon. In case of significance of the interaction between factors, TableCurve 3D software was used to obtain the response surface curves.

\section{RESULTS AND DISCUSSION}

According to the summary of the analysis of variance (Table 2), the interaction between salinity levels (SL) and salicylic acid concentrations (SA) significantly $(\mathrm{p}<0.01)$ influenced all variables analyzed, except the internal $\mathrm{CO}_{2}$ concentration $(\mathrm{Ci})$ and instantaneous water use efficiency (WUEi). The salinity levels, on the other hand, significantly affected the $C i$, transpiration $(E)$, stomatal conductance $(g s), \mathrm{CO}_{2}$ assimilation rate $(A)$ and $C E i$ of soursop plants cv. 'Morada Nova', at 180 days after transplanting. The concentrations of salicylic acid had significant effect on $g_{S}, A$ and $C E i$.

According to the regression equation in Figure $2 \mathrm{~A}$, for $\mathrm{CO}_{2}$ assimilation rate, soursop plants that were not subjected to the application of salicylic acid had their $\mathrm{CO}_{2}$ assimilation rate reduced when irrigated using water with $\mathrm{ECW}$ greater than $1.4 \mathrm{dS} \mathrm{m} \mathrm{m}^{-1}$, obtaining the lowest value of $A$ (4.130 mmol $\mathrm{CO}_{2} \mathrm{~m}^{-2} \mathrm{~s}^{-1}$ ) when irrigated with water of $4.0 \mathrm{dS} \mathrm{m}^{-1}$.

On the other hand, the application of salicylic acid up to the concentration of $1.4 \mathrm{mM}$ promoted an increase in $\mathrm{CO}_{2}$ assimilation rate even when plants were exposed to salinity, and the highest $A$ (8.20 mmol $\mathrm{CO}_{2} \mathrm{~m}^{-2} \mathrm{~s}^{-1}$ ) was obtained in plants subjected to salicylic acid concentration of $1.4 \mathrm{mM}$ and irrigated with water of $1.4 \mathrm{dS} \mathrm{m}^{-1}$, corresponding to an increase of $9.33 \%\left(0.70 \mathrm{mmol} \mathrm{H}_{2} \mathrm{O} \mathrm{m} \mathrm{m}^{-2}\right)$ when compared to plants grown under $\mathrm{ECw}$ of 1.4 $\mathrm{dS} \mathrm{m} \mathrm{m}^{-1}$ and $0 \mathrm{mM}$ of SA.

The beneficial effect of salicylic acid on $\mathrm{CO}_{2}$ assimilation rate, verified in plants subjected to concentrations of up to $1.4 \mathrm{mM}$, may be related to the capacity of salicylic acid to improve enzymatic and photosynthetic activities, while also maintaining the balance between the production and elimination of reactive oxygen species (BATISTA et al., 2019).

For stomatal conductance (Figure 2B), plants subjected to salicylic acid concentrations up to 1.05 $\mathrm{mM}$ obtained an increase in $g s$, regardless of the electrical conductivity of irrigation water, and the highest stomatal conductance $(0.088 \mathrm{~mol}$ $\mathrm{H}_{2} \mathrm{O} \mathrm{m} \mathrm{m}^{-2} \mathrm{~s}^{-1}$ ) was obtained in plants subjected to salicylic acid concentration of $1.05 \mathrm{mM}$ and irrigated with water of $1.64 \mathrm{dS} \mathrm{m}^{-1}$. However, the increase in salicylic acid concentrations above $1.05 \mathrm{mM}$ caused reductions in stomatal conductance, with lowest value of $g s\left(0.044 \mathrm{~mol} \mathrm{H}_{2} \mathrm{O} \mathrm{m} \mathrm{m}^{-2}\right)$ obtained in plants subjected to a concentration of $3.6 \mathrm{mM}$ and irrigated with water of $4.0 \mathrm{dS} \mathrm{m}^{-1}$, corresponding to a reduction of $50 \%\left(0.044 \mathrm{~mol} \mathrm{H}_{2} \mathrm{O} \mathrm{m} \mathrm{m}^{-2} \mathrm{~s}^{-1}\right)$ when compared to plants with higher $g s$. 
Table 2. Summary of the analysis of variance for $\mathrm{CO}_{2}$ assimilation rate $(A)$, stomatal conductance $(g s)$, transpiration $(E)$, $\mathrm{CO}_{2}$ internal concentration $(\mathrm{Ci})$, instantaneous carboxylation efficiency $(\mathrm{CE} i)$ and instantaneous water use efficiency (WUEi) of soursop plants irrigated with saline waters and subjected to foliar application of salicylic acid, at 180 days after transplanting.

\begin{tabular}{ccccccc}
\hline \multirow{2}{*}{ Source of variation } & \multicolumn{7}{c}{ Mean squares } \\
\cline { 2 - 6 } & $A$ & $g s$ & $E$ & $C i$ & $C E i$ & $W U E i$ \\
\hline Salinity levels (SL) & $17.32^{* *}$ & $0.0024^{* *}$ & $1.04^{* *}$ & $1909.72^{*}$ & $0.0004^{* *}$ & $0.88^{\mathrm{ns}}$ \\
Linear regression & $61.02^{* *}$ & $0.0047^{* *}$ & $3.20^{* *}$ & $6795.07^{* *}$ & $0.0016^{* *}$ & $3.14^{\mathrm{ns}}$ \\
Quadratic regression & $1.24^{\mathrm{ns}}$ & $0.0036^{*}$ & $0.40^{\mathrm{ns}}$ & $7.29^{\mathrm{ns}}$ & $0.0001^{\mathrm{ns}}$ & $0.02^{\mathrm{ns}}$ \\
Salicylic acid (SA) & $5.40^{* *}$ & $0.0005^{*}$ & $0.23^{\mathrm{ns}}$ & $1239.93^{\mathrm{ns}}$ & $0.0002^{* *}$ & $0.82^{\mathrm{ns}}$ \\
Linear regression & $3.54^{\mathrm{ns}}$ & $0.0010^{*}$ & $0.58^{\mathrm{ns}}$ & $92.96^{\mathrm{ns}}$ & $3.2 \times 10^{-5 \mathrm{~ns}}$ & $0.24^{\mathrm{ns}}$ \\
Quadratic regression & $11.67^{* *}$ & $0.0006^{\mathrm{ns}}$ & $0.01^{\mathrm{ns}}$ & $3420.15^{\mathrm{ns}}$ & $3.5 \times 10^{-4^{* *}}$ & $0.74^{\mathrm{ns}}$ \\
Interaction (SL x SA) & $3.58^{* *}$ & $0.0019^{* *}$ & $0.43^{* *}$ & $1136.19^{\mathrm{ns}}$ & $0.0002^{* *}$ & $0.64^{\mathrm{ns}}$ \\
Blocks & $14.58^{* *}$ & $0.0013^{* *}$ & $0.26^{\mathrm{ns}}$ & $5941.55^{* *}$ & $0.0002^{* *}$ & $6.48^{* *}$ \\
Residue & 1.25 & 0.0002 & 0.11 & 728.25 & 0.00001 & 0.57 \\
\hline CV (\%) & 17.45 & 18.06 & 17.30 & 12.54 & 20.42 & 21.82 \\
\hline
\end{tabular}

ns, ${ }^{*}{ }^{* *}$ respectively not significant, significant at $\mathrm{p}<0.05$ and significant at $\mathrm{p}<0.01$. CV: Coefficient of variation.

(A) $A=6.717+1.205^{* *} \mathrm{ECw}-0.4629^{*} \mathrm{ECw}^{2}+0.9887^{* *} \mathrm{SA}-0.3458^{* *} \mathrm{SA}^{2}$

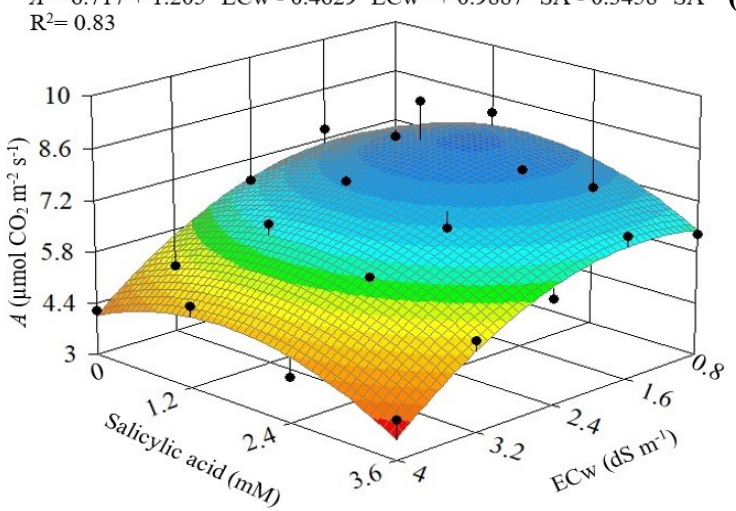

(C) $\quad E=1.94+0.4383^{* *} \mathrm{ECw}-0.1439^{* *} \mathrm{ECw}^{2}+0.0549^{* *} \mathrm{SA}-0.0351^{* *} \mathrm{SA}^{2}$

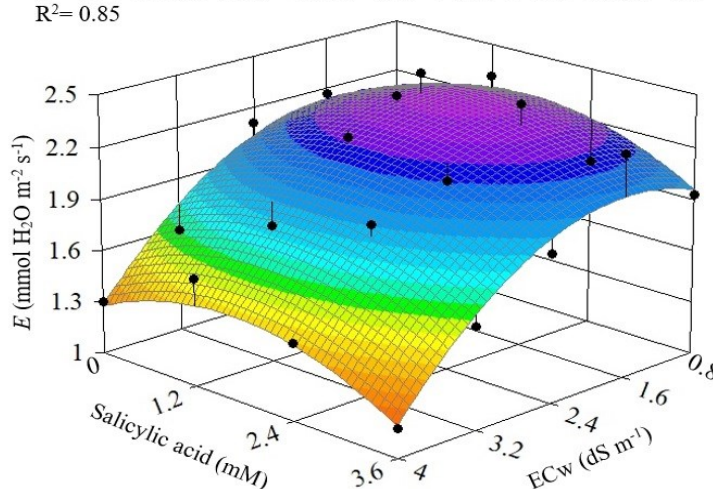

(B)
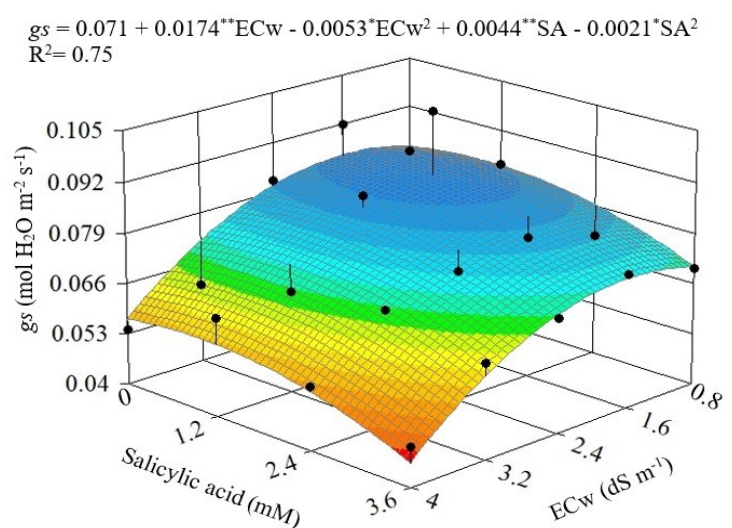

(D)

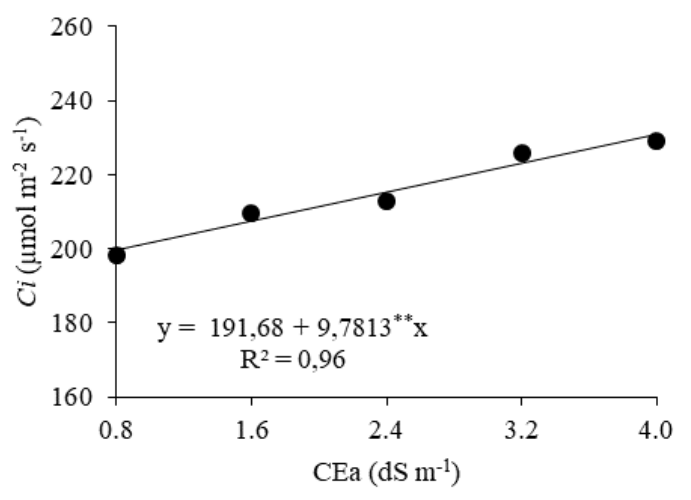

${ }^{*},{ }^{* *}$ - significant at $\mathrm{p} \leq 0,05$ e $\mathrm{p} \leq 0,01$, respectively.

Figure 2. $\mathrm{CO}_{2}$ assimilation rate $-A(\mathrm{~A})$, stomatal conductance $-g s(\mathrm{~B})$ and transpiration $-E(\mathrm{C})$ of soursop plants, as a function of the interaction between water salinity - $\mathrm{ECw}$ and salicylic acid concentrations; and internal $\mathrm{CO}_{2}$ concentration $\mathrm{Ci}$ (D) as a function of the electrical conductivity of water - ECw, at 180 days after transplanting. 
The increase in stomatal conductance (Figure 2B) in plants subjected to a concentration of $1.4 \mathrm{mM}$ led to a higher $\mathrm{CO}_{2}$ assimilation rate (Figure 2A). This response can be attributed to the role of salicylic acid in inducing plant tolerance to salt stress, acting on the increase in the activity of antioxidant enzymes. In addition, salicylic acid induces the alteration of carbohydrate metabolism in plants, and thus the soluble sugars, especially nonreducing sugars, accumulate to function as osmotic regulators (DONG; WANG; SHANG, 2011). Methenni et al. (2018), evaluating the effect of salicylic acid $(0 ; 0.5$ and $1.0 \mathrm{mM})$ on olive plants (Olea europaea L.) under salt stress $(0$ and $200 \mathrm{mM}$ of $\mathrm{NaCl}$ ), verified that the application of salicylic acid at the concentration of $1.0 \mathrm{mM}$ promoted increments in $\mathrm{CO}_{2}$ assimilation rate and stomatal conductance, when compared to the control treatment $(0 \mathrm{mM})$.

Regarding the transpiration of soursop (Figure 2C), plants that did not receive application of salicylic acid $(0 \mathrm{mM})$ and were irrigated with water of electrical conductivity greater than $1.5 \mathrm{dS} \mathrm{m} \mathrm{m}^{-1}$ showed reduction in $E$, and its lowest value (1.39 mmol $\mathrm{H}_{2} \mathrm{O} \mathrm{m}^{-2} \mathrm{~s}^{-1}$ ) was obtained in plants grown with water of $4.0 \mathrm{dS} \mathrm{m}^{-1}$. However, it was verified that the plants subjected to SA concentration of 0.8 $\mathrm{mM}$ and $\mathrm{ECw}$ of $1.5 \mathrm{dS} \mathrm{\textrm {m } ^ { - 1 }}$ attained the highest transpiration $\left(2.30 \mathrm{mmol} \mathrm{H}_{2} \mathrm{O} \mathrm{m}^{-2} \mathrm{~s}^{-1}\right)$. The reduction of leaf transpiration occurs mainly due to the reduction in the total water potential caused by the increase in salt concentration, and such response stands out as a water saving strategy during the critical period (SOUSA et al., 2014).

The increase in the electrical conductivity of irrigation water promoted an increase in the internal $\mathrm{CO}_{2}$ concentration (Figure 2D), equal to $5.10 \%$ per unit increment in $\mathrm{ECw}$. In relative terms, there was an increase of $15.69 \%\left(31.2 \mu \mathrm{mol} \mathrm{m} \mathrm{m}^{-2} \mathrm{~s}^{-1}\right)$ in the $\mathrm{Ci}$ of plants irrigated with water of highest salinity (4.0 $\mathrm{dS} \mathrm{m}{ }^{-1}$ ) compared to that of plants subjected to the lowest salinity level $\left(0.8 \mathrm{dS} \mathrm{m}^{-1}\right)$.

The increase in $C i$ may be related to the degradation of the photosynthetic apparatus in response to the senescence of leaf tissues, resulting from the stress caused by excess salts (SILVA et al., 2013). Similar results were obtained by Lima et al. (2020) in acerola plants (Malpighia emarginata) under salt stress $\left(0.8\right.$ and $\left.4.5 \mathrm{dS} \mathrm{m}^{-1}\right)$, where the increase in internal $\mathrm{CO}_{2}$ concentration in plants irrigated with water of highest salinity $\left(4.5 \mathrm{dS} \mathrm{m}^{-1}\right)$ was attributed to the low activity of the enzyme ribulose-1.5-biphosphate carboxylase oxygenase (RuBisCO).

The instantaneous carboxylation efficiency (CEi) was also affected by the interaction between factors (SL x SA) and, according to the regression equations (Figure 3), plants had their $C E i$ reduced when irrigated using water with $\mathrm{ECW}$ greater than $0.8 \mathrm{dS} \mathrm{m} \mathrm{m}^{-1}$, regardless of the concentrations of salicylic acid. However, it is noted that the highest

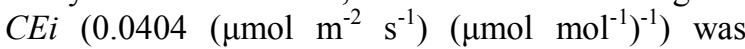
obtained in plants subjected to a concentration of 1.4 $\mathrm{mM}$ and irrigated with water of $0.8 \mathrm{dS} \mathrm{m}^{-1}$, corresponding to an increase of $10.99 \% \quad(0.004$ $\left.\left(\mu \mathrm{mol} \mathrm{m} \mathrm{s}^{-2}\right)\left(\mu \mathrm{mol} \mathrm{mol}^{-1}\right)^{-1}\right)$ in $C E i$ when compared to control plants $(0 \mathrm{mM})$ irrigated with $0.8 \mathrm{dS} \mathrm{m}^{-1}$ water.

The beneficial effect of salicylic acid on the instantaneous carboxylation efficiency, verified in plants subjected to a concentration of $1.2 \mathrm{mM}$, may be related to the capacity of salicylic acid to increase RuBisCO activity and stimulate potassium absorption, maintaining a high $\mathrm{K}^{+} / \mathrm{Na}^{+}$ratio, consequently increasing the content of ATP in plants (LEE; DAMODARAN; ROH, 2014).

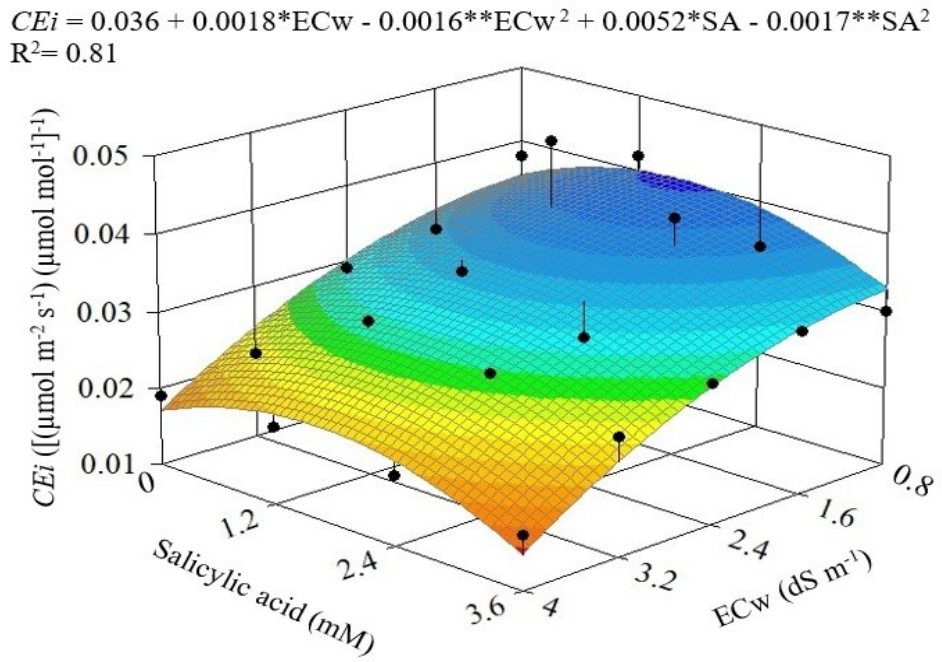

* ** - significant at $\mathrm{p} \leq 0,05$ e $\mathrm{p} \leq 0,01$, respectively.

Figure 3. Instantaneous carboxylation efficiency - CEi of soursop plants, as a function of the interaction between water salinity - ECw and salicylic acid concentrations, at 180 days after transplanting. 
There was interaction between salinity levels and salicylic acid concentrations only for plant height at 210 and 270 DAT (Table 3). The salinity levels of irrigation water significantly affected $(\mathrm{p}<0.01)$ all variables analyzed, except the relative growth rate in stem diameter $\left(\mathrm{RGR}_{\mathrm{SD}}\right)$. Salicylic acid concentrations significantly influenced plant height at 210 and 270 DAT, stem diameter at 210 DAT and relative growth rate in stem diameter $\left(\mathrm{RGR}_{\mathrm{SD}}\right)$.

Table 3. Summary of the analysis of variance for plant height (PH), stem diameter (SD) at 210 and 270 days after transplanting (DAT) and relative growth rates in plant height $\left(\mathrm{RGR}_{\mathrm{PH}}\right)$ and in stem diameter $\left(\mathrm{RGR}_{\mathrm{SD}}\right)$ in the period from 210 to 270 DAT, of soursop plants irrigated with saline waters and subjected to foliar application of salicylic acid.

\begin{tabular}{|c|c|c|c|c|c|c|}
\hline \multirow{4}{*}{ Source of variation } & \multicolumn{6}{|c|}{ Mean squares } \\
\hline & \multicolumn{2}{|c|}{$\mathrm{PH}$} & \multicolumn{2}{|c|}{ SD } & \multirow{3}{*}{$\mathrm{RGR}_{\mathrm{PH}}$} & \multirow{3}{*}{$\mathrm{RGR}_{\mathrm{SD}}$} \\
\hline & \multicolumn{4}{|c|}{ Days after transplanting } & & \\
\hline & 210 & 270 & 210 & 270 & & \\
\hline Salinity levels (SL) & $1795.39^{* *}$ & $3266.21^{* *}$ & $54.46^{* *}$ & $73.97^{* *}$ & $6 \times 10^{-6 * *}$ & $3 \times 10^{-6 \mathrm{~ns}}$ \\
\hline Linear regression & $3685.21^{* *}$ & $8789.40^{* *}$ & $145.81^{* *}$ & $234.41^{* *}$ & $12 \times 10^{-6 * *}$ & $4 \times 10^{-6 n s}$ \\
\hline Quadratic regression & $2295.48^{*}$ & $1768.01^{*}$ & $51.23^{*}$ & $52.46^{\mathrm{ns}}$ & $4 \times 10^{-7 \mathrm{~ns}}$ & $5 \times 10^{-6 n s}$ \\
\hline Salicylic acid (SA) & $2689.12^{* *}$ & $1219.84^{* *}$ & $23.41^{*}$ & $8.46^{\mathrm{ns}}$ & $3 \times 10^{-7 \mathrm{~ns}}$ & $9 \times 10^{-6 * *}$ \\
\hline Linear regression & $206.67^{\mathrm{ns}}$ & $590.80^{\mathrm{ns}}$ & $0.32^{\mathrm{ns}}$ & $0.02^{\mathrm{ns}}$ & $2 \times 10^{-6 \mathrm{~ns}}$ & $5 \times 10^{-6 \mathrm{~ns}}$ \\
\hline Quadratic regression & $7459.35^{* *}$ & $2653.35^{* *}$ & $42.21^{*}$ & $0.74^{\mathrm{ns}}$ & $2 \times 10^{-6 \mathrm{~ns}}$ & $56 \times 10^{-5 * *}$ \\
\hline Interaction (SL x SA) & $311.11^{*}$ & $347.79^{* *}$ & $10.22^{\mathrm{ns}}$ & $8.69^{\mathrm{ns}}$ & $2 \times 10^{-7 \mathrm{~ns}}$ & $8 \times 10^{-6 \mathrm{~ns}}$ \\
\hline Blocks & $108.05^{\mathrm{ns}}$ & $83.75^{\text {ns }}$ & $17.21^{\mathrm{ns}}$ & $222.10^{* *}$ & $3 \times 10^{-7 \mathrm{~ns}}$ & $7 \times 10^{-6 n s}$ \\
\hline Residue & 140.61 & 103.36 & 7.77 & 8.39 & $8 \times 10^{-7}$ & $3 \times 10^{-3}$ \\
\hline CV $(\%)$ & 7.79 & 5.66 & 12.17 & 10.39 & 29.74 & 29.58 \\
\hline
\end{tabular}

Plants irrigated with $1.9 \mathrm{dS} \mathrm{m}^{-1}$ water and subjected to salicylic acid concentration of $2.0 \mathrm{mM}$ attained the highest growth in plant height (Figure $4 \mathrm{~A}$ and $4 \mathrm{~B}$ ), equal to 179 and $217 \mathrm{~cm}$, at 210 and 270 DAT, respectively. Plants irrigated with $4.0 \mathrm{dS} \mathrm{m}^{-1}$ water and under the control treatment $(0$ $\mathrm{mM}$ ) had the lowest $\mathrm{PH}$, equivalent to 115.9 and $144.6 \mathrm{~cm}$, at 210 and 270 DAT, respectively.

The beneficial effect of salicylic acid at the concentration of $2.0 \mathrm{mM}$ observed on plant height at 210 and 270 DAT may be related to the higher photosynthetic efficiency, along with the best nitrogen fixation capacity induced by salicylic acid (FARHANGI-ABRIZ; GHASSEMI-GOLEZANI 2018). On the other hand, the reduction in $\mathrm{PH}$ as a function of salinity occurs due to the water deficit and reduction in nutrient absorption, induced by the osmotic effect and, consequently, restricting gas exchanges, as observed in the present study (Figure 4A, 4B, 4C and 4D).

The increase in saline levels of irrigation water negatively affected the SD (Figure 4C) of soursop cv. 'Morada Nova', at 210 and 270 DAT, with decreases of 6.69 and $5.74 \%$ per unit increase in $\mathrm{ECw}$, at 210 and $270 \mathrm{DAS}$, respectively. The decrease in growth in SD may be related to the increase in the osmotic pressure of soil solution and, consequently, the reduction in the availability of water and nutrients for plants, which results in lower growth (LIMA et al., 2015).

Soursop stem diameter was influenced by the salicylic acid concentrations at 210 DAT, and the regression equation (Figure 4D) shows that plants subjected to the concentration of $1.9 \mathrm{mM}$ stood out with the highest value $(23.99 \mathrm{~mm})$. When comparing the $\mathrm{SD}$ in relative terms, there was an increase of $9.63 \%(2.31 \mathrm{~mm})$ in plants subjected to the salicylic acid concentration of $1.9 \mathrm{mM}$ in comparison to those cultivated under the concentration of $0 \mathrm{mM}$.

The greater growth in SD at 210 DAT up to the salicylic acid concentration of $1.9 \mathrm{mM}$ (Figure $4 \mathrm{D})$ is related to the regulatory effects on physiological and biochemical processes in plants, such as its ability to prevent the decrease in auxin and cytokinin levels, leading to a better cell division in the apical meristem of the root, thereby promoting plant growth (SHAKIROVA et al., 2003)

The increase in irrigation water salinity reduced the relative growth rate in plant height in the period from 210 to $270 \mathrm{DAT}$ and, according to the regression equation (Figure $5 \mathrm{~A}$ ), there was a $13.64 \%$ reduction per unit increase in $\mathrm{ECW}$. In relative terms, there was a reduction of $48.98 \%\left(0.0019 \mathrm{~cm} \mathrm{~cm}^{-1}\right.$ day $\left.^{-1}\right)$ in the $\mathrm{RGR}_{\mathrm{PH}}$ of plants irrigated with water of highest salinity $\left(4.0 \mathrm{dS} \mathrm{m}^{-1}\right)$ in comparison to those cultivated with the lowest salinity level $\left(0.8 \mathrm{dS} \mathrm{m}^{-1}\right)$. 
(A)

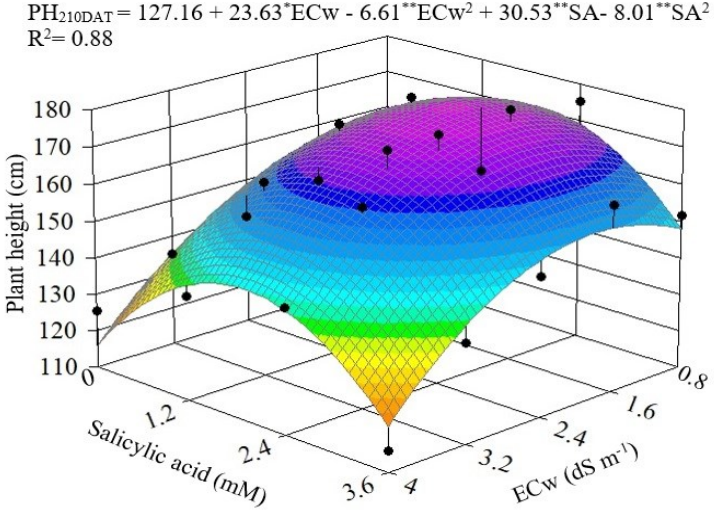

(C)

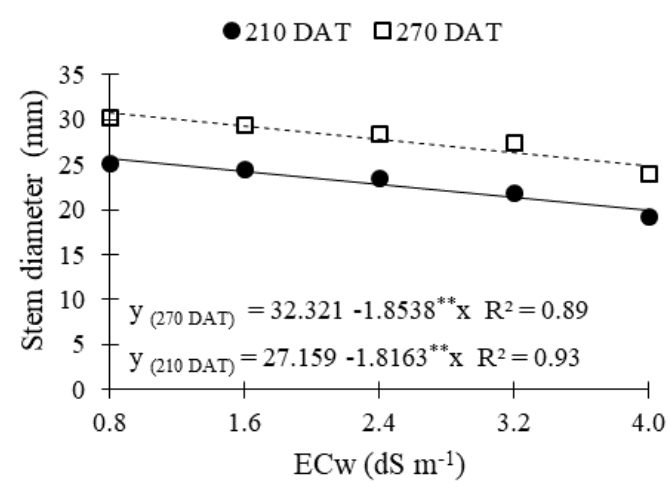

(B)

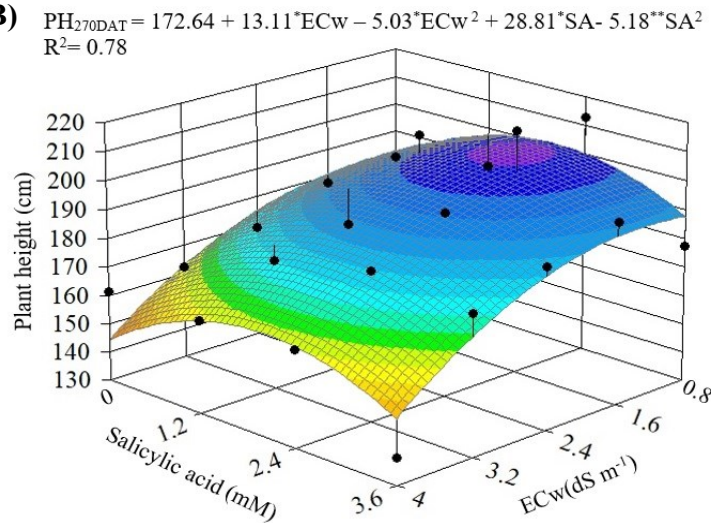

(D)

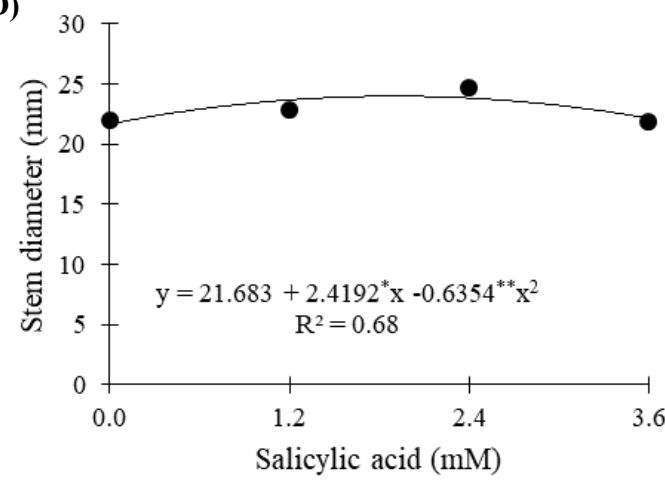

${ }^{*}, * *$ - significant at $p \leq 0,05$ e $p \leq 0,01$, respectively.

Figure 4. Plant height - PH of soursop as a function of the interaction between water salinity - ECw and salicylic acid concentrations at 210 (A) and 270 (B) days after transplanting - DAT; stem diameter at 210 and 270 DAT - (C) and stem diameter at 210 DAT (D), respectively as a function of ECw and salicylic acid concentrations.

(A)

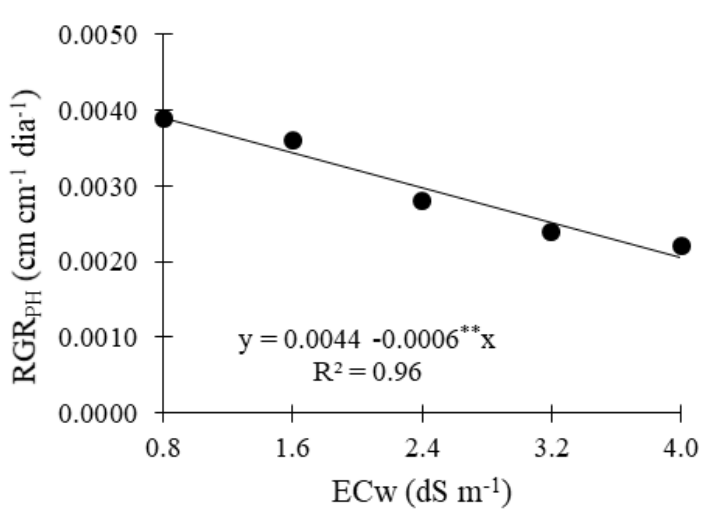

(B)

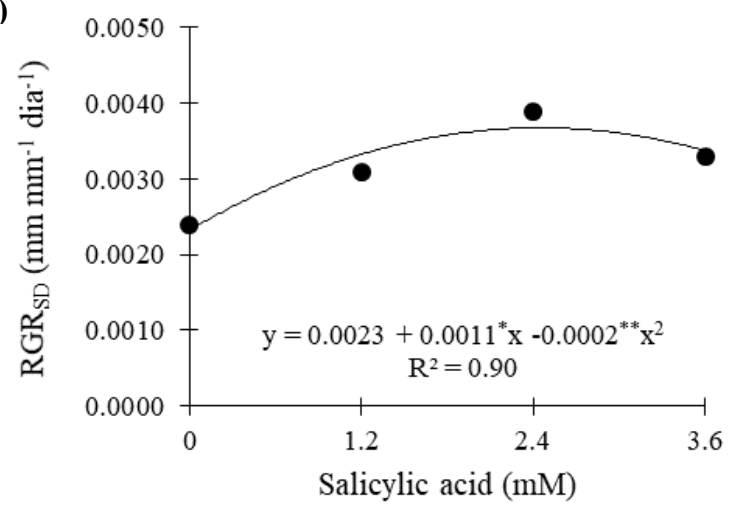

\footnotetext{
${ }^{*}, * *$ - significant at $\mathrm{p} \leq 0,05$ e $\mathrm{p} \leq 0,01$, respectively.
}

Figure 5. Relative growth rate of plant height - $\operatorname{RGR}_{\mathrm{PH}}(\mathrm{A})$ of soursop, as a function of the electrical conductivity of irrigation water and relative growth rate of stem diameter - $\mathrm{RGR}_{\mathrm{SD}}(\mathrm{B})$ as a function of salicylic acid concentrations, in the period from 210 to 270 days after transplantation.

The concentrations of salicylic acid promoted an increase in the relative growth rate of stem diameter $\left(\mathrm{RGR}_{\mathrm{SD}}\right)$ of the soursop cv. 'Morada Nova' and, according to the regression equation (Figure $5 \mathrm{~B}$ ), plants subjected to a concentration of $2.75 \mathrm{mM}$ stood out with the highest value of $\mathrm{RGR}_{\mathrm{SD}}(0.0038$ $\mathrm{mm} \mathrm{mm} \mathrm{may}^{-1}$ ). There was an increase of $39.47 \%$ $\left(0.0015 \mathrm{~mm} \mathrm{~mm}^{-1}\right.$ day $\left.^{-1}\right)$ in the $\mathrm{RGR}_{\mathrm{SD}}$ of plants subjected to the salicylic acid concentration of 2.75 $\mathrm{mM}$ in comparison to plants subjected to the SA concentration of $0 \mathrm{mM}$.

The increase in the relative growth rate in stem diameter, observed in plants subjected to concentrations of up to $2.75 \mathrm{mM}$ (Figure 4B), 
reflects the ability of salicylic acid to prevent the reduction of cytokinin and auxin, which stimulates cell division and consequently plant growth (ESTAJI; NIKNAM, 2020).

\section{CONCLUSIONS}

Irrigation with saline water compromises the growth and gas exchange of soursop cv. 'Morada Nova'. Exogenous application of salicylic acid induces tolerance to salt stress in soursop plants, as their relative growth in stem diameter, transpiration, stomatal conductance, photosynthesis and instantaneous carboxylation efficiency were favored by the application of salicylic acid, even when exposed to salinity.

\section{ACKNOWLEDGMENTS}

To the National Council for Scientific and Technological Development - CNPq for granting financial aid (Proc. CNPq 430525/2018-4) and to the Coordination for the Improvement of Higher Education Personnel - CAPES for granting the scholarship to the first author.

\section{REFERENCES}

ABBASZADEH, B. et al. Improving water use efficiency through drought stress and using salicylic acid for proper production of Rosmarinus officinalis L. Industrial Crops and Products, 144: e111893, 2020.

ANDRADE, W. L. et al. Bradyrhizobium inoculation plus foliar application of salicylic acid mitigates water deficit effects on cowpea. Journal of Plant Growth Regulation, 1: 1-12, 2020.

BATISTA, V. C. V. et al. Salicylic acid modulates primary and volatile metabolites to alleviate salt stress-induced photosynthesis impairment on medicinal plant Egletes viscosa. Environmental and Experimental Botany, 167: e103870, 2019.

BENINCASA, M. M. P. Análise de crescimento de plantas, noções básicas. 2. ed. Jaboticabal, SP: FUNEP, 2003. $41 \mathrm{p}$.

BENTO, E. B. et al. Estudio etnofarmacológico comparativo en la región del Araripe de la Annona muricata L. (Graviola). Revista Cubana de Plantas Medicinales, 21: 9-19, 2016.

BISTGANI, Z. E. et al. Effect of salinity stress on the physiological characteristics, phenolic compounds and antioxidant activity of Thymus vulgaris L. and Thymus daenensis Celak. Industrial Crops and Products, 135: 311-320, 2019.

CAVALCANTE, F. J. A. Recomendação de adubação para o Estado de Pernambuco: 2 . aproximação. 3. ed. Recife, PE: Instituto Agronômico de Pernambuco, 2008. 212 p.

DAUDA, A. O. et al. An assessment of the preservative potentials of soursop (Annona muricata) seed oil on plantain and orange juice. Global Advanced Research Journal of Microbiology, 7: $113-120,2018$

DONG, C. J.; WANG, X. L.; SHANG, Q. M. Salicylic acid regulates sugar metabolism that confers tolerance to salinity stress in cucumber seedlings. Scientia Horticulturae, 129: 629-636, 2011 .

ESTAJI, A.; NIKNAM, F. Foliar salicylic acid spraying effects' on growth, seed oil content, and physiology of drought-stressed Silybum marianum L. plant. Agricultural Water Management, 234: e106116, 2020.

FARHANGI-ABRIZ, S.; GHASSEMI-GOLEZANI, K. How can salicylic acid and jasmonic acid mitigate salt toxicity in soybean plants. Ecotoxicology and Environmental Safety, 147: 1010-1016, 2018.

FERREIRA, D. F. SISVAR: A computer analysis system to fixed effects split plot type designs. Revista Brasileira de Biometria, 37: 529-535, 2019.

GHARBI, E. et al. Comparison between the impacts of two different modes of salicylic acid application on tomato (Solanum lycopersicum) responses to salinity. Plant Signaling \& Behavior, 13: e1469361, 2018

KHAN, M. S. et al. An investigation on the role of salicylic acid alleviate the saline stress in rice crop (Oryza sativa L). Biocatalysis and Agricultural Biotechnology, 18: e101027, 2019.

LEE, S. Y.; DAMODARAN, P. N.; ROH, K. S. Influence of salicylic acid on rubisco and rubisco activase in tobacco plant grown under sodium chloride in vitro. Saudi Journal of Biological Sciences, 21: 417-426, 2014.

LIMA, G. S. et al. Water status, cell damage and gas exchanges in West Indian cherry (Malpighia emarginata) under salt stress and nitrogen fertilization. Australian Journal of Crop Science, 
14: 319-324, 2020.

LIMA, L. A. et al. Tolerância da berinjela à salinidade da água de irrigação. Revista Agroambiente, 9: 27-34, 2015.

MAGALHÃES, I. D. et al. Gas exchange, photochemical efficiency, and yield of Jatropha curcas irrigated with saline water. Australian Journal of Crop Science, 14: 802-809, 2020.

MEDEIROS, J. F. Qualidade de água de irrigação e evolução da salinidade nas propriedades assistidas pelo GAT nos Estados de RN, PB e CE. 1992. 173 f. Dissertação (Mestrado em Engenharia Agrícola: Área de concentração em Irrigação e Drenagem) - Universidade Federal da Paraíba, Campina Grande, 1992.

METHENNI, K. et al. Salicylic acid and calcium pretreatments alleviate the toxic effect of salinity in the Oueslati olive variety. Scientia Horticulturae, 233: 349-358, 2018.

NOREEN, S. et al. Foliar application of salicylic acid with salinity stress on physiological and biochemical attributes of sunflower (Helianthus annuus L.) crop. Acta Scientiarum PolonorumHortorum Cultus, 16: 57-74, 2017.

PIRASTEH-ANOSHEH, H. et al. Salicylic acid induced salinity tolerance through manipulation of ion distribution rather than ion accumulation. Journal of Plant Growth Regulation, 36: 227-239, 2017.

POÓR, P. et al. Effects of salicylic acid on photosynthetic activity and chloroplast morphology under light and prolonged darkness. Photosynthetica, 57: 367-376, 2019.

RICHARDS, L. A. Diagnosis and improvement of saline and alkali soils. Washington: U.S, Department of Agriculture. 1954. 160 p.

RODRIGUES, V. S. et al. Yield of maize crop irrigated with saline waters. Revista Brasileira de Engenharia Agrícola e Ambiental, 24: 101-105, 2020.

SÁNCHEZ, C. F. B. et al. Genetic diversity among soursop genotypes based on fruit production. Bioscience Journal, 34: 122-128, 2018.

SÃO JOSÉ, A. R. et al. Atualidades e perspectivas das Anonáceas no mundo. Revista Brasileira de Fruticultura, 36: 86-93, 2014. status of wheat seedlings induced by salicylic acid and salinity. Plant Science, 164: 317-322, 2003.

SILVA, A. R. A. et al. Trocas gasosas em plantas de girassol submetidas à deficiência hídrica em diferentes estádios fenológicos. Revista Ciência Agronômica, 44: 86-93, 2013.

SILVA, E. M.. et al. Growth and gas exchanges in soursop under irrigation with saline water and nitrogen sources. Revista Brasileira de Engenharia Agrícola e Ambiental, 22: 776-781, 2018.

SILVA, J. E. et al. Salicylic acid in the physiological priming of onion seeds subjected to water and salt stresses. Revista Brasileira de Engenharia Agrícola e Ambiental, 23: 919-924, 2019.

SOUSA, G. G. de et al. Growth, gas exchange and yield of peanut in frequency of irrigation. Revista Ciência Agronômica, 45: 27-34, 2014.

SZEPESI, Á. Influence of exogenous salicylic acid on antioxidant enzyme activities in the roots of salt stressed tomato plants. Acta Biologica Szegediensis, 52: 199-200, 2008

TEIXEIRA, P. C. et al. Manual de métodos de análise de solo. 3.ed. Brasília, DF: Embrapa, 2017. $573 \mathrm{p}$.

UNITED STATES - Department of Agriculture. Keys to soil taxonomy. Natural Resources Conservation Service. 2014. 372p.

VELOSO, L. L. S. A. et al. Quality of soursop (Annona muricata L.) seedlings under different water salinity levels and nitrogen fertilization. Australian Journal of Crop Science, 12: 306-310, 2018 .

VELOSO, L. L. S. A. et al. Effects of saline water and exogenous application of hydrogen peroxide $\left(\mathrm{H}_{2} \mathrm{O}_{2}\right)$ on soursop (Annona muricata L.) at vegetative stage. Australian Journal of Crop Science, 13: 472, 2019.

SHAKIROVA, F. M. et al. Changes in the hormonal 